\title{
Sustainable Health for All? The Tension Between Human Security and the Right to Health Care
}

Alexander K. Lautensach

School of Education, University of Northern British Columbia, 4837 Keith Ave. Terrace, B.C. V8G 1K7, Canada;

E-Mail: alexl@unbc.ca; Tel.: +1 2506153334; Fax: +1 2506155478

Submitted: 23 April 2014 | In revised form: 8 November 2014 | Accepted: 9 November 2014 |

Published: 24 February 2015

\begin{abstract}
In the current global environmental crisis medical aid and disaster relief is given by the UN and its branches, by governments and by NGOs, who regard it as their duty to address large-scale humanitarian catastrophes. The duty to give medical aid rests on traditional interpretations of health security and on the bioethical imperatives to relieve suffering and to save lives. However, those principles are not easily reconciled in the current situation of global environmental change and the threats it poses to human security. The global demand for health care has already outpaced resources in many regions, and those resources are likely to decline further. An ethic based on more comprehensive concepts of human security can lessen the contradictions between ethical priorities because it takes into account environmental security. However, that approach leads to clashes with common interpretations of human rights, including the so-called right to health care. The argument presented in this paper states that, under the imperative of ensuring the survival for humanity in acceptable and sustainable ways, the latest generation of human rights pertaining to health care and environmental quality have become ungrantable. While this does not render them negligible, it does necessitate a new approach to global development aid and health security, with severe consequences for individual autonomy.
\end{abstract}

Keywords: bioethics; global health care; health security; human rights; sustainability

\section{Introduction}

At the dawn of a new millennium, humanity finds itself on a crowded new planet with fewer resources and less hospitable climates-overall a tougher place to make a living. This change is the cumulative result of our species' ever-increasing demands on the biosphere and the global environmental changes that we set in motion decades ago [1]. The average number of people reportedly affected by 'natural' disasters (mainly earthquakes, droughts, floods, famines, storms, epidemics) quintupled from 1975 to 2010 [2]. Even as

(C) 2015 by the authors; licensee Librello, Switzerland. This open access article was published under a Creative Commons Attribution License (http://creativecommons.org/licenses/by/3.0/). 
percentages of the world population, the numbers of victims increased from $1.5 \%$ to $4.8 \%$.

This trend contrasts against a reported decline in victims of armed conflicts $[3,4]$ and against a decrease of the number of deaths from natural disasters, presumably caused by improvements in organisation and experience on the part of relief organisations [5]. The increase in the volume of humanitarian relief efforts ([5] p. 12) has kept the percentage of unmet demands at roughly 40 percent from 2000 to 2012, even though the total demand for humanitarian relief (measured as the UN's consolidated appeals for help) increased 4.7 fold over that time [5].

The question arises: how long can this increase in quality and quantity of humanitarian relief continue to keep up with the rising demands? The trend of rising demands is certain to persist as humanity's growing environmental impact and ongoing global environmental change exert further pressure on the biosphere. Even tectonic disasters reap ever higher tolls as population densities keep increasing. The global public has become jaded in the face of incessant reports of casualties and damage. Contributions to charities have stalled over recent years ([5] p. 11).

Besides the provision of food, potable water and shelter, the bulk of humanitarian assistance consists of public health measures in the pursuit of health security - protection from threats such as acute trauma and communicable disease. The WHO [6] summarises those threats as "emerging and rapidly spreading diseases, environmental change, the danger of bioterrorism, sudden and intense humanitarian emergencies caused by natural disasters, chemical spills or radioactive accidents, and the impact of HIV/AIDS." The current campaign against the Ebola epidemic in West Africa faces unprecedented numbers of people at risk. At the level of the individual, this protection extends to personal and family health care beyond the short-term focus of large-scale disasters. There, too, the demand has increased-from 2000 to 2008 global per capita health expenditures almost doubled ([7] p. 137). Burgeoning costs, increasing incidences of many environmentally caused diseases, and new pathogens have imparted further pressure on healthcare systems that are already strained by growing populations. In worldwide personal healthcare, too, assistance is struggling to keep pace with demand.

In humanitarian terms, extrapolating these dynamics into the longer term gives reason for concern. Yet the statements and projections made at the highest levels of national governments and the UN reveal little evidence that such prospective concern expressed at the ground level is shared among the leaders of humanity. Vague and optimistic statements about future 'economic growth' and technological development into unspecified directions take the place of evidence-based assessments of human insecurity. For example, The International Covenant on Economic, Social and Cultural Rights (ICESCR) [8], based on the Universal Declaration of Human Rights, commits its parties to cater to universal rights including an "adequate standard of living," clothing, housing, the "highest attainable standard of physical and mental health" and access to its underlying determinants (such as clean water, sanitation, food, nutrition and housing), and freedom from hunger. In its "principle of progressive realisation" the ICESCR obliges members to "take steps, individually and through international assistance and cooperation, especially economic and technical, to the maximum of its available resources, with a view to achieving progressively the full realization of the rights recognized in the present Covenant by all appropriate means." As another example, the US-based Global Health Council [9] aims to contribute the necessary "information and resources" to all efforts towards improvement and equity in health care. They name as the main challenges "insufficient financing, lack of inter-agency coordination, poorly-functioning information systems, health worker shortages and supply interruptions." Both mission documents imply that it is unconditionally possible to "improve the health of those living in the developing world" by "improving the effectiveness of programs and overall funding," [9] even in the face of abundant and convincing refutations of such cornucopian exuberance and techno-optimism $[10,11]$. The ICESCR [8] acknowledges that some of the rights (for example, the right to health) may be difficult in practice to achieve in a short period of time due to resource constraints, and it requires them to act as best they can within their means. However, it also implies an inevitable upward trend that, given enough time, all of humanity can enjoy the full realisation of their rights. That implication is where its fallacy lies. Sustainable health security for 'all', while absolutely worthwhile as an ideal, has become absolutely elusive for a population exceeding seven billion.

This paper aims to explain this widening gap between aspirations and projections about health security, to assess the underlying assumptions and values, and to suggest how our thinking and moral priorities need to change if health security is to be established for all of humanity. Based on those considerations, the paper offers three propositions. Firstly, I shall argue that the trend of increasing relief efforts coupled with increasing misery is profoundly unsustainable, which renders morally questionable any policies that do not take that lack of sustainability into account. Relief efforts depend on economic power, and the world's economic power is no longer growing as rapidly; in fact, abundant evidence suggests that it is bound to decline soon $[12,13]$.

Rather than just to accept an even greater increase in human misery once relief efforts inevitably taper off, it would help if alternative options could be considered proactively. My second proposition focuses on those options, especially on changes to the ethics that inform both humanitarian assistance and healthcare- 
the ethics of health security. Assuming that the first proposition is true, that the increase in misery is bound to outpace our efforts to mitigate it, humanitarian principles demand that we re-examine policies and underlying ethics proactively instead of continuing a losing battle against what many interpret as natural population control mechanisms that have begun to dominate the ecology of our species [14-16]. The development of new and more sustainable policy alternatives depends on revised ethics.

A re-examination and revision of health care ethics will attract much controversy. As a salient feature of the new ethics, my third proposition will state that the so-called 3rd generation human rights (including the 'right' to health care) are becoming increasingly ungrantable and should therefore be neither claimed nor promised. My argument will be based on the fact that, unlike other human rights, the 3rd generation depend largely on the availability of environmental resources, many of which are becoming ever scarcer. We will explore the implications for policy and practice in healthcare and humanitarian assistance.

\section{Present Forms of Humanitarian Assistance and Public Health Policies are Unsustainable}

Disasters such as earthquakes, famines, epidemics, and severe weather events are generally referred to as 'natural' or even as 'acts of God', although at this stage those attributes fully apply only to tectonic events. The rest can usually be traced to anthropogenic environmental change-various combinations of climate change, declines in ecosystem health and in resource availability, or the effects of violent conflict. Those changes are in turn caused by our increased industrial and economic activity, our increased consumption, global inequities in power and wealth, and the sheer increase in our numbers [17]. Those effects combine to a collective environmental impact on the biosphere's support structures that has been causing global environmental crises on many fronts. The anthropogenic 'natural' disasters mentioned above are one manifestation of those crises.

Other manifestations of the global environmental crises include pollution, resource scarcity, and the rapid loss of biodiversity. For the first time in human history those manifestations have reached global proportions, and their unprecedented magnitude suggests a quantum leap in the way in which humanity impacts on the biosphere. That quantum leap has been expressed in the word overshoot [18].

Collective ecological overshoot amounts to 'living beyond our means.' [19] Some scientific definitions rely on the comparison of humanity's ecological footprint with the Earth's bioproductive capacity [20]. A population whose footprint exceeds the amount of accessible productive land is clearly in regional overshoot [21]. Other definitions focus on the transgression of specific ecological boundaries that describe a safe operating space for sustainable living [22].

Overshoot has severe consequences. Human populations, like all other animal populations, obtain their sustenance from ecosystems which provide so-called 'ecosystem services.' [23] Human populations are special in that they employ technology to maximise the benefits of those ecosystem services. But regardless of this technological windfall, the capacities of local ecosystems remain limited. Generally, the environmental impact $I$ of a human population on local ecosystems is described by the $I=P A T$ formula, where $P$ means population size, $A$ stands for the affluence or economic means per capita, and $T$ represents the technological impact per capita $[24,25]$. The maximum sustainable impact, also referred to as carrying capacity ([26] p. 126) is thus described as the product of the three variables. It can be reached by small populations with a high-impact lifestyle or by larger populations where each individual demands less in terms of support services. Overshoot occurs when a population exceeds the maximum sustainable impact, where the services of the local ecosystems are being overtaxed. As a result, depending on the fragility of those ecosystems, they may undergo irreversible structural changes [18,27-29]. Inevitably the consequence for the population is such that various biological regulatory mechanisms lead to a decrease in population health, an increase in mortality, and eventually a drop in population size, below the system's carrying capacity. Numerous precedents from animal populations have allowed ecologists to characterize and predict those dynamics with impressive accuracy.

Despite their eventual severity, the consequences of overshoot for a human population may not always ensue right away [30]. A population may avoid immediate negative consequences as it may obtain the shortfall from other regions that are either underpopulated, defenceless, or otherwise disempowered. The practice is, however, often unjust and supports unsustainable patterns of consumption. Globally, of course, the shortfall is appropriated from future generations. Sooner or later (the timing is difficult to predict) the cumulative effects of resource scarcity, environmental deterioration, and poor public health will lead to the shrinkage of economies, with further decreases in per capita resource availability and in overall human security, and a rapid population decline.

Against that backdrop, the prospects for further intensifying humanitarian relief efforts (for large populations) and healthcare (for individuals and their families) seem unrealistic, at least in the long term. The increase in their economic costs is bound to clash with the decrease in budgets. Economies cannot remain stable, let alone grow, in the absence of an adequate supply of natural resources, renewable and nonrenewable. Moreover, addressing this vast problem only at the symptomatic level is morally objectionable. It is difficult to come up with a moral justification for a strategy that focuses predominantly on short-term hu- 
manitarian assistance and healthcare and fails to address the underlying chronic causes of large-scale human misery [31]. With the major economies shrinking, countries will increasingly focus on their own national welfare and the interests of their elites, while the world's poorest will be left to their own devices. Costintensive healthcare options will be increasingly restricted to those who can afford to pay for them. A recent study indicated that many of the programs and policies that pass for 'sustainable development' are probably neither sustainable, nor do they qualify as genuine development [32]. This bias towards short term solutions cannot be justified merely by pointing out the political difficulties and cultural taboos associated with addressing the underlying systemic problems. Yet, the question deserves serious consideration whether those moral objections to the current approach really warrant a change in practices that are almost universally regarded as not only 'good' but as the best possible course of action in the pursuit of health security. The answer depends on the extent to which the ethics that underlies those practices is itself sustainable.

\section{Health Security is Part of Human Security}

In order to come up with sustainable solutions, the ethics of humanitarian assistance and healthcare must be regarded within the more comprehensive ethical context of human security [26,33], which has much in common with Potter's [34] 'bioethics'. From its first formulation in the UNDP's 1994 Development Report [35], human security has been conceived primarily as a moral imperative, namely the realisation that the security of human beings requires more than a secure state, that it also depends on the absence of structural and cultural violence [36] at the individual level. And since human individuals, unlike states, are capable of sensations and emotions, human security was recognised as partly contingent on those particular states of mind that we tend to associate with well-being and good health.

In the context of public health and humanitarian crises, efforts to improve human security include a relative safety from acute infectious disease, minimum complements of safe fresh water and adequate nutrition, and a formal guarantee for basic human dignity. Concern for human security also became extended further into the future. It has become acceptable to express concern with the future well-being of one's children and their generation, and their posterity. This long-term humanitarian concern has gradually come to inform the agenda of human security, as indicated by some common definitions of sustainable development $[37,38]$. Health care plays a prominent role in those agenda as illustrated by three of the eight Millennium Development Goals $[39,40]$.

Along with health, the range of factors determining the state of an individual's human security is de- scribed by the seven dimensions of economic, food, health, environmental, personal, community and political security ([35] pp. 24-33), or the four pillars of military/strategic security, economic security, healthrelated security, and environmental security [41]. Environmental security focuses on the complex interactions between human populations and their ecological support structures, namely the source and sink functions of their host ecosystems. The dependence of many security determinants on a healthy environmental support system that imposes limits on growth has led to the notion of environmental security as the 'ultimate security' $[42,43]$. Such comprehensive models of human security have attracted some criticism (e.g. [44]); however, those critics offer little help with security concerns expressed at the grassroots, nor do they pay much attention to the primacy of ecological dependency.

The major contribution of those comprehensive models of human security in the context of this paper is that they place healthcare and humanitarian assistance into a larger, more comprehensive set of requirements that can "protect the vital core of all human lives in ways that enhance human freedoms and human fulfilment" ([45] p. 8). Based on those comprehensive models of human security, development agencies operating under national, super-national or non-governmental umbrellas have extended their security concept into ethical dimensions. This extension is evident in several key policy documents of the United Nations. In the Secretary-General's Millennium Report the UN's security agenda are defined as 'freedom from fear,' and their development agenda as 'freedom from want.' $[46,47]$ The UN's guiding principles on security are thus paraphrased in negative terms as freedom from a condition that is evidently undesirable [17]. Similarly, Alkire ([48] p. 2) defined the objective of human security as 'to safeguard the vital core of all human lives from critical pervasive threats, and to do so without impeding long-term human flourishing.' As a further step, some regard such freedoms as a new generation of human rights, as was mentioned on the example of the ICESCR [8]-a point to which we will return later.

While the formulation and widespread advocacy of a human security ethic seems a move in the right direction, the definition in terms of freedoms seems unsatisfactory for its lack of logical rigour, its paternalistic subjectivity and relativity of the criteria involved, and its neglect of systemic limits [41]. Positive definitions of human security (e.g. [49]) avoid some of those objections, but further progress is only possible by prioritising ecological integrity as an essential requirement for human security [50] and by addressing specific sources of insecurity. To name two examples relating to healthcare, the WHO's 2006 World Health Report points to the health-related dimension of insecurity, caused in part by a severe shortage of health care personnel, especially in poor countries $[51,52]$. The UN's Millennium Ecosystem Assessment [53] identified severe detriments to population health 
arising from global environmental deterioration [54]. It is important to note that recognising the ethical primacy of environmental security neither depends on, nor necessarily demands, a turn towards ecocentrism. In fact, the practice of the mainstream media labelling as 'environmentalist' anybody and everybody who expresses concern about environmental security is misleading and entirely unjustified [43].

The dependence of health security, along with all other aspects of human security, on environmental security becomes most evident when we examine its prospects over the long term, i.e. its sustainability. Sustainability is described by the balance between supporting the quality of life for a human population and the continued functioning of its environmental support structures, namely ecosystems ([55] p. 198). Ecosystems consist of local communities of species and their physical environment. They serve as sources of food, fresh water, raw materials and energy, and they recycle the population's wastes. At the most elementary level, then, sustainability just means continued survival. However, human populations can survive in different modes. Recognising that the survival of societies is contingent on collective choices, Potter [34] distinguished five distinct modes of human survivalmere, miserable, unjust, idealistic, and acceptable. Together they describe the total range of possible survival modes; currently a combination of unjust and miserable survival dominates globally. Each mode is characterised by a corresponding state of public health. Given the central importance of human well-being and of principles of justice in human security I suggest that sustainable human security on a global scale is identical with the acceptable survival of humanity, meaning an acceptable quality of health for the population at large according to new metrics such as the Genuine Progress Indicator [56].

With respect to health care, acceptable survival of the population will mean minimising human suffering through the equitable distribution of scarce resources of care. That includes doing without costly symptomatic interventions while maximizing the benefit of low-cost preventive care and of lifestyle adjustments. This follows from the extent to which cost intensive health care systems such as those in North America and Europe currently depend on wealthy economies which are in turn unsustainable $[57,58]$ as well as globally unjust.

To summarise the sequence of causation, unsustainable practices sooner or later lead a population into overshoot, which in turn erodes environmental support structures and decreases their capacity to deliver resources and to accept wastes in the future. This loss of ecological integrity and capacity means that the environmental security of the population is compromised, which can manifest itself in shortages of food, energy, or of other commodities, or in elevated levels of pollution, and sometimes in the emergence of new pathogens. Such changes invariably di- minish population health and lead to economic decline, civil disorder, and vulnerability to external enemies [59], all of which compromise health further. Evidence is provided by the historical precedents of cultures that disappeared as a result of this sequence of effects [60], and by the correlation of pathogen emergence with ecosystem destruction [52]. The upshot is that whatever safeguards may be in place to protect the economic security of a population, its public health, its national security, and the rule of law -they seem of little help in the long term unless sustainability and environmental security are guaranteed. This resonates with Barnett's [61] finding of a mutual dependence between environmental security and peace and with Myers' [42] thesis of environmental security as the 'ultimate security.' As for population health, its dependence on ecological integrity has been extensively documented [62-65]. We can establish causal connections not only between unsustainable practices, environmental insecurity and health crises but also between excessive population size and compromised population health. We also saw that intensified health care assistance for large populations is not a sustainable option, no matter how vociferously it is demanded. In other words, much of the ethics informing current practices of healthcare is not sustainable. This puts into question its underlying beliefs and priorities, particularly certain purported human rights, including the 'right to health care' with, as we shall see, some significant political ramifications.

\section{The Ethical Challenge to Make Health Security Sustainable}

The practice of humanitarian assistance and of health care in general is governed by the aims to relieve suffering and to save lives, under the four bioethics principles of beneficence, non-maleficence, autonomy and justice [66]. These moral principles, among other sources, have generally served the healthcare professions well as the ethical foundation of their professional conduct. Nevertheless, problematic aspects remain, among them the unjust allocation of scarce resources that has culminated in today's extreme global inequities in terms of health care quality [67]. In response to this problem, a discourse of rights has developed among advocates of justice in global health care, rights that are linked to the greater body of human rights.

As mentioned earlier, many popular conceptualisations of human security are founded on human rights. These rights developed historically in three stages, each based on a set of basic needs [68]. The first generation of human rights was civil and political in nature and was based on the cardinal value of freedom. The second generation are economic and social human rights, based on the cardinal value of human equality. At this stage a third generation of rights is being formulated, as illustrated by the UN 
and numerous major NGOs focusing on the right of every global citizen to enjoy freedom from fear and freedom from wants $[8,47]$. Many welcome those freedoms as overdue additions to the list of human rights specified in the UN's Universal Declaration of Human Rights [69]. They extend on the rights specified in Article 25 of the Declaration which refers to "the right to a standard of living adequate for the health and well-being of himself and of his family, including food, clothing, housing and medical care and necessary social services..." [69] In terms of environmental security those freedoms amount to certain quality attributes pertaining to environmental support systems, sometimes referred to as 'environmental rights.' The UN's Millennium Development Goals [39, 70] refer to them as the right to clean air, safe potable water, adequate nutrition, shelter, the safe processing of wastes, and adequate health care. The document reveals no awareness of the limited capacity of ecological support structures to supply those resources. Likewise, UNFPA's State of the World Population Report frames overpopulation as a problem of unrecognised rights to make free reproductive choices and 'unmet needs' [71]. Some have claimed that future generations also have a right to adequate health care $[8,72,73]$. Not surprisingly, people widely disagree over the extent to which citizens of affluent societies should recognize third generation rights for global humanity and for future generations.

In our examination of environmental security we established that the purification of air and water, the provision of foods and shelter, and the processing of wastes are directly carried out by ecosystems, many of them local, involving varying extents of 'management'. It follows that the sustainable provision of those services depends on the biological integrity of those ecosystems $[50,74]$. Likewise, the health of a population is evidently affected by the state of its ecosystems $[27,65]$. Accordingly, it would make sense for human communities to claim the right that 'their' ecosystems not be harmed or diminished in their capacities. The fact that such a claim is not usually made, and that instead the demands pertain exclusively to the human recipients of those services represents both a grave logical fallacy and a strategic error in judgment by human rights advocates. Failing to recognise and emphasise the indispensable role of those support structures amounts to an opportunity wasted. The integrity of an ecosystem can, given sufficient care, experience and motivation, be maintained sustainably, barring any major external threats such as climate change. Among the conditions of such a policy would be that the total environmental impact of the community does not exceed the sustainable maximum, i.e. the ecosystem's carrying capacity.

In contrast, claiming that the individual community member has a right to a certain minimum quality of service regardless of environmental conditions makes no sense because no-one has the power to grant such a demand, not even the most absolute dictator, once the population's impact has exceeded that threshold. The reason is that satisfying this demand depends ultimately on physical resources, which are of course limited-as opposed to conducive human attitudes or legislation. Overshoot effectively prevents any government from converting the so-called 'right' into an opportunity for all. Thus, those third generation 'environmental rights,' including the 'right' to adequate health care, belong in a different category from the other human rights, the category of ungrantable 'rights.' Being grantable, however, is an essential property of any right [75]. Therefore, a right that cannot be granted is no right at all (hence our use of inverted commas), and it makes no sense to promise or to claim it.

Our suggestion that claiming ungrantable 'rights' also represents a strategic error in judgment is also based on the effect that such a claim diminishes the status of other rights to which realistic and legitimate claims could be made. For example, if the UN's Human Rights Council added to the list of human rights the right to own a circus, clearly ungrantable, the entire list would as a result acquire a less serious, less binding, and more conditional appearance [76]. This would be regarded as a disservice by humanists who harbour genuine concern for human rights and their enforcement. Including ungrantable 'rights' among the list is likely to diminish the sense of urgency with which all human rights ought to be respected worldwide. On the health care side, people become habituated to media images of sick individuals from poor countries and they take it for granted that whatever 'right' to health care those people or their advocates might proclaim is quite immaterial to their own privileged situation. This tacit assumption can all too easily be extended to inequities in political representation, in self expression and sexual preference, and to other presumably 'self-evident' rights, all entirely grantable, which would compromise civil society worldwide.

The problem of ungrantable 'rights' does of course not diminish the policy makers' duty to promote the environmental security and public health of communities, especially when it comes to the world's disempowered. The fundamental conceptual link between rights and duties remains unaffected by the absence of grantability on the side of the right. As I suggested above, the concept of ecosystem integrity can be instrumental in formulating policy guidelines that would go a long way towards guaranteeing that rights can be fulfilled. However, under conditions of overshoot, a gap appears between the discourse of rights, which is in part rendered wishful thinking, and the discourse of duties, which remains unaffected. Consequently, moral reasoning, in order to convince, can no longer rely on rights-based arguments but needs to make greater use of arguments invoking duty, utility and virtue. This would also help with a more concise formulation of codes of behaviour and their translation into effective policies and legislation. 
Of course this shift in the argument only applies to third generation 'rights' whose grantability depends heavily on environmental resources. In contrast, the fulfilment of grantable rights depends primarily on human behaviour and preferences. In the light of this distinction, the question arises whether ungrantable 'rights' are of any use at all. Specifically we might ask, is there any benefit in insisting on the individual global citizen's entitlement to adequate health care, considering that such adequate healthcare is seldom forthcoming and is bound to diminish further?

\section{From Health Care 'Rights' to Health Care Demands}

The preceding discussion emphasised the need to use rights-based arguments sparingly and prudently when debating health security and human security in general, and to invoke grantable rights in different ways and on different occasions compared to those kinds of demands that are based on ungrantable 'rights.' Heretofore I will refer to the latter as 'environmental demands,' and specifically to 'health care demands.' I do not mean to insinuate that such demands have no place in debates about humanitarian assistance and basic health care-on the contrary: The qualities of air and water, of nutrition, of shelter, of the ways of recycling wastes, and the status of public health are still among the best indicators to assess the health security of a community. And they can help bolster some legitimate rights-based arguments, namely in connection with the right to distributive justice. I perceive at least three distinct benefits of health care demands, and for environmental demands in general.

First, in the case of a community or region that has not yet reached the maximum sustainable environmental impact, health care demands can highlight situations of injustice and inequity. Based on claims for distributive justice they would help promote initiatives to elevate the quality of health care for society's poorest and their standard of living in the community. For example, elevated local incidences of cancer in society's poorest are often used to bolster demands on the authorities to explore possible causes and to implement equitable policies to improve prevention, screening and treatment.

Secondly, in situations where the maximum sustainable impact has already been exceeded health care demands serve to highlight that very circumstance. No other physical observation illustrates the fact of ecological overshoot more clearly than the widespread squalor caused by polluted air and water, famine, and the resulting abundance of ill health [27]. Vociferous demands for mitigation can make a significant difference politically. Also, comparisons of national footprints with available bioproductive areas $[77,78]$ have made it abundantly clear that overshoot has now been the norm for many regions and historical reality for the globe since the mid-1980s [53,
$58,79]$. Yet the worldwide efforts by powerful groups to ensure that information about overshoot is delayed, distorted, ignored or denied require concerted efforts to disseminate such information and to educate the public $[11,80]$. The language of health care demands and environmental demands is one that everyone understands, even if those demands are bound to remain largely unmet. The causal connections between overshoot and poor health have not yet widely entered the public's awareness. Calls for fairness and equity can help to direct public attention to regions where overshoot is worst.

Thirdly, health care demands are the mainstay of the discourse on justice in bioethics. An effective way to illustrate the widening gap between global rich and poor is to compare the health indicators that reflect the qualities of their respective lives, in addition to the often invoked data on per capita consumption or income. Regardless of the extent of overshoot, such comparisons highlight the injustice inherent in the global economic order, its trading schemes, and its underlying maldistribution of political power [81]. While insisting on one's right to a certain quality of health care may not lead to improvements, demands for equitable health care are more justifiable and authorities are often more inclined to listen to them; after all, they can invoke a right that is grantable.

Insisting on health care demands in those contexts represents of course only the first step in an argument that necessarily leads to a discussion of Potter's [34] five modes of survival, and of measures that might lead us from the current prevailing global mixture of miserable and unjust modes towards more acceptable alternatives. However, that "Great Transition" [82] confronts us with another problem where many of the grantable human rights-the ones that refer mostly to human behaviour and social capital in a civil society-conflict with health security and environmental security in general.

\section{Reconciling Health Security with Human Rights and Civil Liberties}

Our assessment boils down to this: Worldwide efforts by humanitarian organisations and healthcare systems accomplish a great deal of good in terms of at least a modicum of health security for much of humanity. But their efforts indirectly cause an inordinate amount of harm, especially to future generations, through their contribution to further growth of populations and economies. Moreover, they do not address the sources of the problems. This harm will continue until our global population, through a massive population reduction, reaches either a few million who enjoy all the trappings of modern diagnostic and therapeutic medicine, or a billion or two who receive the equivalent of adequate health care of a mid-rank country such as Cuba, or some solution in between $[82,83]$. The challenge lies in getting there with a minimum of suffering. 
History abounds with well-intentioned efforts by powerful rulers to enforce measures for the 'common good,' which arguably required that the individual rights and liberties of some or all of their subjects be curtailed. Article 29 of the Universal Declaration of Human Rights [69] serves that purpose, albeit not in a dictatorial way. Even in retrospect it is often difficult to assess whether such a specific curtailment in fact led to preferable outcomes. Certainly human rights were often violated in the course of such measures. In principle, every law that is passed represents a compromise between benefits to society and sacrifices to individual autonomy. This basic dilemma is amplified many times in scenarios depicting the transition towards sustainability [82].

The demand to attain sustainability can be entirely justified on the basis of intergenerational justice. Such moral extensionism towards future generations is evident in mainstream definitions of sustainability as in the Brundtland document [37]. However, the argument of intergenerational justice requires that the welfare of future generations be weighed against the rights and liberties of existing humans, and that is where many of those definitions falter [34]. The requisite drastic changes in lifestyle choices towards greater efficiency, reduced consumption, adaptation to global changes, and organisational restructuring, most likely accompanied by a reduction in the global population, would necessitate either an unprecedented amount of consensus on sacrificing our current privileges or a draconian repression of individual autonomy [84-86]. Neither option sits well with the humanistically inclined advocates of intergenerational justice. Of course, denying the conflict is always an option: In 2005, then Secretary-General Kofi Annan ([47] p. 1) stated in his report 'In Larger Freedom' advocating development, security and human rights for all, "The world must advance the causes of security, development and human rights together, otherwise none will succeed. Humanity will not enjoy security without development, it will not enjoy development without security, and it will not enjoy either without respect for human rights." The problem lies with his naive use of the word 'all.'

Another way to justify the demand to attain sustainability is by the ecocentric appeal to spare the Earth further ecological devastation from the hands of humanity. In fact, there is good reason to assume that only an ecocentric ethic can ultimately provide the moral basis for sustainable behaviour $[26,87]$. The arguments, which for reasons of space cannot be repeated here, rely on the overarching importance of environmental security and avoiding errors in 'managing nature.' To ecocentrists, even of the light green persuasion, many human rights and liberties carry less moral weight than the survival of other species and the existence and integrity of entire ecosystems and the biosphere. This has given cause for occasional charges of 'ecofascism' from rights-oriented circles
([88] p. 362). For ecocentrists the dilemma between human rights and environmental preservation usually presents less of a challenge because they value the latter so much more. The particular moral priorities of ecocentrism were also the reason why traditionally ecocentric ethics were considered incompatible with the ethics of health care, where the moral priorities lie squarely on the side of 'doing no harm' to humans. Yet the dependence of sustainable public health on environmental integrity suggests that at this juncture ecocentric ethics resembling Potter's [34] 'bioethics' are likely to lead to better health care for more future people than traditional humanitarian ethics could.

How could such an ecocentric ethics of health care help us reconcile health security with human rights? Avoiding overshoot would ensure that adequate resources will support the health of future generations and that the emergence of new pathogens from compromised ecosystems will be minimised [52]. The sacrifice comes in the form of severe curtailment to individual rights of the citizenry. The cohort of health care recipients is also likely to change. If current trends were allowed to continue, the gap between rich and poor would be even wider and the percentage of affluent citizens would be smaller because of shrinking economies. A more equitable redistribution would most likely come at the cost of individual rights ([17] p. 161). Also, the immigration of millions of ecological refugees from inundated coastlines and inhospitable local climates into countries that are willing to accept them will have altered demographic profiles. In the face of those changes, the following suggested measures would help render health care environmentally safe and sustainable.

- The shrinking of economies and the growing numbers of disenfranchised masses will render it even more urgent that drastic steps towards more equitable distribution of health care expenditures will finally be implemented. This would mean the end of public funding for elective treatments, for costly diagnostic equipment and for intensive hightech therapies. The ethics of triage would assume a prominent role in medical decision-making. Still, more equitable health care would lower average mortality.

- The constriction at the therapeutic side of health care will be compensated, at least in part, by an expansion of the preventive side [89]. Appropriate changes to lifestyle and nutrition would no longer be left to the autonomous decision of the citizen or unpredictable market forces but be imposed across society by legislation. For example, manufacturers of 'junk food' will be forced to switch to healthier products and consumers will have only relatively healthy foods to choose from, locally produced by sustainable methods, and lower on the food chain [54].

- The worldwide trends towards the commercialisation of disease and the commodification of treatment would have to be reversed. Just as state 
security should not be left to private contractors, so should the other aspects of human security be exempted from privatization, particularly at this juncture where the well-being of more and more people depends on decreasing funds. If health security is accepted as the overarching goal then its provision must not be restricted to those who can pay for it. Moreover, private enterprise is less accessible to enforcement and verification. This change of course will raise many ethical challenges about the reorientation of medical research, about the extent to which pharmaceutical companies will be allowed to participate, about development aid, and about our policies towards epidemics-which, after all, have evolved as just another biological mechanism of population control and are therefore bound to increase for as long as populations do; the current Ebola epidemic will not be the last instance.

- Above all, no health care resources could be used to support and promote human reproduction -on the contrary, all health care decisions would be informed by the overarching need to aid population attrition. In animal ecology, widespread infertility is recognised as a biological control mechanism that allows a population to curtail its exponential growth. Infertility is among the few such mechanisms that cause relatively little human suffering. The discourse of rights and needs [71] needs to change to a discourse of limits and obligations.

With respect to the four principles of bioethics, the curtailments described above indicate that patient autonomy would be severely reduced under ecocentric ethics of health care [57]. Similar restrictions will be placed on many of the democratic freedoms that citizens of many rich countries have become accustomed to, either as a function of population density in concentrated urban communities [90] or in tightly regulated rural socio-ecological communities $[31,91]$. On the other hand, ecosystems would receive a degree of autonomy of their own [92]. With regards to justice, it should be noted that ecocentric ethics does not necessarily call for greater equity in health care, although it is likely that the withdrawal of many elective services from the general population will lead to political demands to also curtail the health care privileges of the elites. Under ecocentrism the justice principle is merely expanded to include and prioritise the health of ecosystems $[93,94]$. However, prioritising comprehensive health security mandates an equitable approach, because the extent of security in a society is primarily determined by its least secure segment.

As for beneficence and non-maleficence, their importance remains unchanged but under ecocentrism what constitutes good and bad in health care is redefined in a more holistic way that conceives of humans as parts of larger ecological entities (socioecological communities) [91] that have moral standing and interests of their own. While we may continue to benefit from their functioning, we have no right to compromise them for our short-term interests or our pursuit of ungrantable individual 'rights.' The current overarching moral imperative of health care, to save lives, will be given less priority and the relief of suffering, the minimising of utilitarian cost-benefit ratios and the avoidance of ecocide will be emphasized more.

Notwithstanding those encouraging prospects for sustainable health care under ecocentric principles, it remains a fact that most practitioners and policy makers in health care are not ecocentrists. Their decisions seem to be primarily informed by an ethic that Mary Midgley referred to as "relentless humanism". This is illustrated, for example, by the language and the ideals underlying the health care targets of the UN's Millennium Development Goals $[39,70]$, the ICESCR [8] and the Global Health Council [9]. To the determined anthropocentrist the only recourse in the dilemma between rights and security is to weigh the extent to which human rights and liberties will have to be curtailed if the transition is to be accomplished, against the extent that rights and liberties will be lost amidst anarchy, chaos, famine, disease, and incessant warfare over diminishing resources, if sustainability is not achieved [59]. To most people who value the future welfare of their children and grandchildren, this utilitarian comparison of benefits and harms will lead them towards the side of sustainability [95]. Those who place more emphasis on traditional principles and virtues might find this dilemma rather more paralysing. A mere emphasis on distributive justice would dictate again a course change away from elective and preferential treatment and lead to more equitable health care, even though in the face of continued overshoot it may only turn out equitably miserable.

My suggestions apply in principle to all national systems of health care but not to equal extents. Crisp [96] suggested ways in which Third World and developed countries are capable of complementing their respective capacities and needs in a global 'co-development' whereby a more acceptable level of health care can be attained at a global scale. Much of the extra capacity that would be freed up by the elimination of elitist services in rich countries will be sorely needed in poor countries. Thus the reforms towards the new health care need to be implemented in a coordinated fashion around the world, tailored to the specific needs and strengths of regional communities.

The opposition to those reforms, too, will vary among countries but will be massive in many. Where health care has been privatized to a large degree a formidable opposition can be expected from the corporate providers and their privileged clients. It seems unlikely that such private health care providers could be integrated into the new schema. To the extent that countries will be swelled by masses of impoverished refugees, the principle of health care as a business will be less and less useful for their sustainable health 
security. This will constitute a greater problem in North America than in European countries. Another obstacle will be the inertia of education systems, of the media, and of the food, beverage, and agricultural industries that will not easily be persuaded to promptly support and promote the transition to healthier food and life styles. A third direction from where opposition can be expected are staunch advocates of democratic rights and civil liberties who will have difficulties with the removal of unhealthy and unhelpful choices from the grocery shelves as well as from the clinics ([17] $\mathrm{p}$. 162). On top of all that will come vociferous objections on religious and cultural grounds.

The all-important first step towards sustainable global health care will have to be a frank and open discussion of the issues at hand. Global limits, needs and capacities, rights and duties, means and ends must be made explicit and placed on the table in panel discussions, parliamentary debates, academic conferences, classrooms at all levels, governmental organ-

\section{References}

[1] McKibben B. Eaarth: Making a life on a tough new planet. New York, NY, USA: Times Books; 2010.

[2] CRED (Centre for Research on the Epidemiology of Disasters). EM-DAT: The International Disaster Database. Brussels, Belgium: CRED; 2013. Available from: http://www.emdat.be/natural-disasterstrends.

[3] HSRP (Human Security Report Project). Human security report 2012: Sexual violence, education, and war-beyond the mainstream narrative. Vancouver, Canada: Human Security Press. Available from: http://www.hsrgroup.org/human-security-reports/ 2012/overview.aspx.

[4] Pinker S. The better angels of our nature: Why violence has declined. New York, NY, USA: Viking Penguin; 2011.

[5] Buston O, Smith K. Global humanitarian assistance report 2013. UK: Development Initiatives, 2013. Available from: http://www.globalhumanitarian assistance.org/.

[6] WHO (World Health Organisation). World Health Day 2007: High Level Debate Tackled Need for Improved International Health Security. Geneva, Switzerland: WHO; 2013. Available from: http:// www.who.int/world-health-day/previous/2007/activ ities/global_event/en/index.html.

[7] WHO (World Health Organisation). World Health Statistics 2011. Geneva, Switzerland: WHO; 2011. Available from: http://www.who.int/whosis/ whostat/EN_WHS2011_Part2.pdf.

[8] United Nations Office of the High Commissioner for Human Rights. International covenant on economic, social and cultural rights. New York, NY, USA: OHCHR; 1966. Available from: http://www. ohchr.org/en/professionalinterest/pages/cescr.aspx.

[9] Global Health Workforce Alliance. Global isations, election meetings, public hearings, council meetings and any other public forum that promises leverage with the wider public. Precaution needs to trump scientific uncertainty. Population issues must no longer be regarded as taboo [97]. The longer those issues remain below the public horizon the greater the possibility that events will overtake deliberations. What might help is the uncomfortable realisation that, whichever choices are taken and whichever ethics gain the upper hand, the kind of health care as we have come to rely on in affluent countries will not last.

\section{Acknowledgment}

The work for this essay was supported by a grant from the University of Northern British Columbia. Part of the essay appeared in [32]. The author thanks the anonymous reviewers for their constructive and helpful comments. No conflict of interest arises for the author from this publication.

health council: member profile. Geneva, Switzerland: WHO; 2014. Available from: http://www.who.int/work forcealliance/members_partners/member_list/ghc/en/.

[10] Wright R. A short history of progress. Toronto, Canada: House of Anansi Press; 2004.

[11] Rees W. What's blocking sustainability: Human nature, cognition and denial. Sustainability: Science, Practice and Policy. 2010;6(2):13-25. Retrieved on 20 January 2011. Available from: http://sspp.pro quest.com/archives/vol6iss2/1001-012.rees.html.

[12] Heinberg R. Peak everything: Waking up to the century of declines. Gabriola Island, Canada: New Society Publishers; 2007.

[13] Costanza R, Kubiszewski I, Giovannini E, Lovins $H$, McGlade J, Pickett KE, Ragnarsdottir KV, Roberts D, De Vogli R, Wilkinson R. Development: time to leave GDP behind. Nature. 2014;505(7483): 283-285.

[14] Pimentel D. Overpopulation and sustainability. Frontiers in Ecology and the Environment. 2006;4(3): 155-161.

[15] Grossman R. The importance of human population to sustainability. Environment, Development, and Sustainability. 2012;14(3):973-977.

[16] Macbeth $\mathrm{H}$, Collinson $\mathrm{P}$, editors. Human population dynamics: cross-disciplinary perspectives. Cambridge, UK: Cambridge University Press; 2002.

[17] Hempel LC. Environmental governance: the global challenge. Washington, DC, USA: Island Press; 1996.

[18] Catton WR Jr. Overshoot: The ecological basis of revolutionary change. Urbana, IL, USA: University of Illinois Press; 1980.

[19] UNEP-MAB (Millennium Assessment Board). Living beyond our means: Natural assets and human well-being. London, UK: UNEP-WCMC; 2005. Available from: http://www.maweb.org/en/Reports.aspx.

[20] Wackernagel M, Rees W. Our ecological foot- 
print: Reducing human impact on the earth. Oxford, UK: John Carpenter; 1996.

[21] Chambers N, Simmons C, Wackernagel $M$. Sharing natures interest: ecological footprints as an indicator of sustainability. London, UK: Earthscan Publications; 2000.

[22] Rockström J, Steffen W, Noone K, Persson A, Chapin III FS, Lambin E, Lenton TM, Scheffer M, Folke C, Schellnhuber HJ, Nykvist B, de Wit CA, Hughes T, van der Leeuw S, Rodhe H, Sörlin S, Snyder PK, Costanza R, Svedin U, Falkenmark M, Karlberg L, Corell RW, Fabry VJ, Hansen J, Walker B, Liverman D, Richardson K, Crutzen P, Foley J. A safe operating space for humanity. Nature. 2009;461(24September):472-475.

[23] Vitousek PM, Mooney HA, Lubchenko J, Melillo JM. Human domination of earth's ecosystems. Science. 1997;277(25 July):494-499.

[24] Ehrlich PR, Holdren J. The impact of population growth. Science. 1971;171(3977):1212-1217.

[25] York R, Rosa EA, Dietz T. STIRPAT, IPAT and ImPACT: analytic tools for unpacking the driving forces of environmental impacts. Ecological Economics. 2003;46(3):351-365.

[26] Curry P. Ecological ethics: An introduction. 2nd edition. Cambridge, UK: Polity Press; 2011.

[27] McMichael AJ. Human frontiers, environments and disease: past patterns, uncertain futures. Cambridge, UK: Cambridge University Press; 2001.

[28] Wackernagel $M$, Schulz NB, Deumling $D$, Linares AC, Jenkins $M$, Kapos V, Monfreda C, Loh J, Myers N, Norgaards R, Randers J. Tracking the ecological overshoot of the human economy. Proceedings of the National Academy of Sciences (USA). 2002; 99(14):9266-9271.

[29] Meadows D, Randers J, Meadows D. Limits to growth: The 30-year update. White River Junction, VT, USA: Chelsea Green Publishing Co.; 2004.

[30] Raudsepp-Hearne C, Peterson G, Tengo M, Bennett EM, Holland T, Benessaiah K, MacDonald GK, Pfeifer L. Untangling the environmentalist's paradox: Why is human well-being increasing as ecosystem services degrade? BioScience. 2010;60(8):576-589.

[31] Rees WR. Avoiding collapse: an agenda for sustainable degrowth and relocalizing the economy. Vancouver, Canada: Canadian Centre for Policy Alternatives; 2014.

[32] 'Genuine' development is based on long-term considerations of human welfare within systemic limits, as proposed in Lautensach AS, Lautensach SW. Why 'sustainable development' is often neither: a constructive critique. Challenges in Sustainability. 2013;1(1):3-15. See also [56].

[33] O'Brien K, St.Clair AL, Kristofferson B, editors. Climate change, ethics and human security. Cambridge, UK: Cambridge University Press; 2010.

[34] Potter VR. Global bioethics: Building on the Leopold legacy. East Lansing, MI, USA: Michigan State University Press; 1988.

[35] UNDP (United Nations Development Pro- gramme). Human development report: New dimensions of human security. New York, NY, USA: Oxford University Press; 1994.

[36] Galtung J. Violence, peace, and peace research. Journal of Peace Research. 1969;6(3):167-191.

[37] WCED (World Commission on Environment and Development). Our common future: The Brundtland Report. Oxford, UK: Oxford University Press; 1987.

[38] UN Millennium Project. Investing in development: A practical plan to achieve the Millennium Development Goals. New York, NY, USA: United Nations; 2005.

[39] United Nations. End poverty 2015: Millennium development goals. New York, NY, USA: United Nations; 2009. Available from: http://www.un.org/ millenniumgoals/.

[40] Chen LC, Leaning J, Narasimhan V, editors. Global health challenges for human security. Cambridge, MA, USA: Harvard University Press; 2004.

[41] Lautensach AK. Expanding human security. Australasian Journal of Human Security. 2006;2(3):5-14.

[42] Myers N. Ultimate security: The environmental basis of political stability. New York, NY, USA: W.W. Norton \& Co.; 1993.

[43] Lautensach SW, Lautensach AK. Environmental security: international, national and human. In: Harris PG, editor. Routledge Handbook of Global Environmental Politics. New York, NY, USA: Routledge; 2013. pp. 246-258.

[44] Buzan B, Waever O, De Wilde J. Security: A framework for analysis. Boulder, CO, USA: Lynne Rienner; 1998.

[45] Commission on Human Security. Human security now. New York, NY, USA: United Nations; 2003.

[46] United Nations. We the peoples: The role of the United Nations in the 21st century. New York, NY, USA: United Nations; 2000. Available from: http:// www.un.org/en/events/pastevents/pdfs/We_The_Peo ples.pdf.

[47] Annan K. In larger freedom: Towards development, security, and human rights for all. Executive Summary. New York, NY, USA: United Nations; 2005. Available from: http://www.un.org/ga/search/view_ doc. asp?symbol=A/59/2005.

[48] Alkire S. A conceptual framework for the Commission on Human Security. Center for Research on Equality, Human Security, and Ethnicity (CRISE). Working Paper 2, Oxford, UK: University of Oxford; 2003. Available from: http://www.crise.ox.ac.uk/ pubs/workingpaper2.pdf.

[49] Hastings D. The human security index: An update and a new release. Document Report Version 1.0. 2011. Available from: http://www.humansecurity index.org/wordpress/wp-content/uploads/2012/02/ hsiv2-documentation-report1_1.pdf.

[50] Westra L. Ecological integrity. In: Mitcham C, editor. Encyclopedia of Science, Technology and Ethics. Vol. 2. D-K. Detroit, MI, USA: McMillan Reference USA; 2005. pp. 574-578. 
[51] WHO (World Health Organisation). World health report. Geneva, Switzerland: WHO; 2006. Available from: http://www.who.int/whr/2006/en/.

[52] Garrett L. Betrayal of trust: The collapse of global public health. New York, NY, USA: Hyperion; 2000.

[53] MAB (Millennium Assessment Board). Millennium ecosystems and human wellbeing. Washington, DC, USA: Island Press; 2005. Available from: http:// www.millenniumassessment.org//en/Products.Synthes is.aspx.

[54] Hales S, Butler C, Woodward A, Corvalan C. Health aspects of the Millennium Ecosystem Assessment. EcoHealth. 2004;1(2):124-128.

[55] Lemons J. Afterword: University education in sustainable development and environmental protection. In: Callicott JB, da Rocha FJR, editors. Earth summit ethics: Toward a reconstructive postmodern philosophy of environmental education. Albany, NY, USA: State University of New York Press; 1996. pp. 193-217.

[56] Donella Meadows Institute. A genuine talk on progress and the genuine progress indicator. Mother Pelican. 2014;10(4):1-4. See also Costanza et al [13].

[57] Jameton A, Pierce J. The ethics of environmentally responsible health care. Oxford, UK: Oxford University Press; 2004.

[58] World Wildlife Fund (WWF). Living planet report: species and spaces, people and places. Gland, Switzerland: WWF International; 2014.

[59] Homer-Dixon T. Environment, scarcity, and violence. Princeton, NJ, USA: Princeton University Press; 1999.

[60] Diamond J. Collapse: How societies choose to fail or succeed. London, UK: Viking Penguin; 2005.

[61] Barnett J. Environmental Security and Peace. Journal of Human Security. 2007;3(1):4-16.

[62] Rapport DJ. The dependency of human health on ecosystem health. Ecosystem Health. 1997;3(3):195-196.

[63] Karr JB. Bridging the gap between human and ecological health. Ecosystem Health. 1997;3(3):197199.

[64] Soskolne CL, Bertollini R. Global ecological integrity and "sustainable development"-cornerstones of public health. WHO European Centre for Environment and Health. Proceedings 1999. Rome, Italy, 3-4 December 1998. Bonn, Germany: World Health Organization.

[65] Chivian E. Environment and health: 7.Species loss and ecosystem disruption-the implications for human health. Canadian Medical Association Journal. 2001;164(1):66-69.

[66] Beauchamp TL, Childress JF. Principles of biomedical ethics. 6th edition. New York, NY, USA: Oxford University Press; 2009.

[67] Dasgupta PS, Ehrlich PR. Pervasive externalities at the population, consumption, and environment nexus. Science. 2013;340(19 April):324-328.

[68] Fien J. Education for the environment: Cur- riculum theorising and environmental education. Geelong, Victoria, Australia: Deakin University Press; 1993.

[69] United Nations. The universal declaration of human rights. New York, NY, USA: United Nations; 1948. Available from: http://www.un.org/en/doc uments/udhr/index.shtml. In thirty articles, the Charter specifies the human right to life, liberty, and security of person; to freedom from discrimination by race, creed, gender, and equality before the law and due process; to a fair and public hearing in case of criminal accusations; to be presumed innocent until proven guilty; to free association and nationality, to freedom of movement; to own property; to freedom of expression and of religion; to democratic choice of representation; to respect for human dignity; to work and to equal pay as well as to leisure; and to a basic humanistic education. Negative rights include freedom from inhuman or degrading treatment or punishment; from arbitrary arrest, detention, or exile. Article 29 recognises appropriate duties and limitations of the rights of the individual for the common good but does not mention ecological limits.

[70] Sachs JD, McArthur JW. The Millennium Project: A plan for meeting the Millennium Development Goals. The Lancet. 2005;365(22January):347-353.

[71] UNFPA (United Nations Population Fund). By choice, not by chance: Family planning, human rights and development. State of the World Population 2012 Report. New York, NY, USA: UNFPA; 2012. Available from: http://www.unfpa.org/public/home/publications/pid/ 12511.

[72] Deckers J. Negative GHIs, the right to health protection, and future generations. Journal of Bioethical Inquiry. 2011;8(2):165-176.

[73] Jameton A, Pierce J. Environment and health: 8. Sustainable health care and emerging ethical responsibilities. Canadian Medical Association Journal. 2001;164(3):365-369.

[74] Karr JB. Measuring biological condition, protecting biological integrity. In: Groom MJ, Meffe GK, Carroll CR, editors. Companion to Principles of Conservation Biology. Sunderland, MA, USA: Sinauer Associates; 2006. Available from: http://www. sinauer.com/groom/article.php?id=23.

[75] Rawls J. A theory of justice. Cambridge, MA, USA: Harvard University Press; 1971. Ungrantable does not necessarily mean unjustifiable. Rawls showed that a right becomes unjustifiable when a person exercising that right impinges on the opportunities of other people exercising the same right. In the case of 'environmental rights,' their impact depends on the total number of people claiming them. Thus they violate Rawls' postulate only if their collective exercise results in the carrying capacity being exceeded. But their property of being ungrantable remains true under all conditions, in the sense that they cannot be guaranteed even by a ruler with the greatest political power and the best intentions. 
[76] This devaluing effect is also evident with legal norms: In Canada there still exists a federal law prohibiting the transport of any alcoholic beverage across a provincial boundary. Needless to say, most citizens are neither aware of this law, nor would they pay it any heed if they were. As an adjunct effect, however, this anachronism renders liquor legislation in general slightly more ridiculous and 'worth ignoring' in the public eye.

[77] Wackernagel M, Onisto L, Callejas Linares A, López Falfán IS, Méndez García J, Suárez Guerrero AI, Guadalupe Suárez Guerrero MA. Ecological footprints of nations: How much nature do they use?-How much nature do they have? Xalapa, Mexico: Centre for Sustainability Studies and San Jose, Costa Rica: Earth Council; 1997. Available from: http://www.ucl.ac.uk/ dpu-projects/drivers_urb_change/urb_environment/pdf_ Sustainability/CES_footprint_of_nations.pdf.

[78] GFN (Global Footprint Network). Ecological footprint atlas. 2009. Available from: http://www. footprintnetwork.org.

[79] Myers N, Norgaards R, Randers J. Tracking the ecological overshoot of the human economy. Proceedings of the National Academy of Sciences. 2002;99(14):9266-9271. Available from: http://www. pnas.org/cgi/reprint/99/14/9266.pdf.

[80] Lautensach AK. Environmental ethics for the future: rethinking education to achieve sustainability. Saarbruecken, Germany: Lambert Academic Publishing; 2010.

[81] A thought experiment can illustrate the fact that health care demands can, in the long run, only satisfy considerations of justice, not considerations of rights. In a highly inequitable society that has exceeded its maximum ecological impact only an elite minority can enjoy the full benefits of abundant health care services, because those in turn depend on ecosystem services. The majority survive (or not) in relative misery. A benign dictator set on reforming this society along environmental demands made by the masses could distribute health care benefits more equitably. This would improve the situation in terms of distributive justice but it cannot bring about acceptable health care for all, thus leaving many demands unmet. Furthermore, neither total utility nor average utility would increase, even if the population has stopped growing.

[82] Raskin P, Banuri T, Gallopín G, Gutman P, Hammond A, Kates R, Swart R. Great transition: the promise and lure of the times ahead. Stockholm Environment Institute Polestar Report no. 10. Boston, MA, USA: SEI; 2002. Available from: http://www.seiinternational.org/publications?pid $=1547$.

[83] The example of Cuba seems apt because this country is one of the few who has made genuine efforts, albeit not entirely voluntarily, to operate sustainably with only a minimum of petroleum products. In time, 'peak oil' will force the rest of the world to develop similar approaches to healthcare; Parker $\mathrm{CL}$, Schwartz BS. Human health and well-being in an era of energy scarcity. In: Heinberg R, Lerch $D$, editors. The Post-Carbon Reader. Heraldsburg, CA, USA: Watershed Media. 2010. pp. 385-405.

[84] Bowers CA. Education, cultural myths, and the ecological crisis: Toward deep changes. Albany, NY, USA: State University of New York Press; 1993.

[85] Daly HE, Cobb JB. For the common good: Redirecting the economy toward community, the environment, and a sustainable future. 2nd ed. Boston, MA, USA: Beacon Press; 1994.

[86] Lautensach AK, Lautensach SW. Summary and conclusions. In: Lautensach AK, Lautensach SW, editors. Human Security in World Affairs: Problems and Opportunities. Chapter 20. Vienna, Austria: Caesarpress; 2013. pp. 411-448.

[87] Lautensach AK. The ethical basis for sustainable human security: a place for anthropocentrism? Journal of Bioethical Inquiry. 2009;6(4):437-455.

[88] Regan T. The case for animal rights. Berkeley, CA, USA: University of California; 1983.

[89] Halstead SB, Walsh JA, Warren KS, editors. Good health at low cost. New York, NY; USA: Rockefeller Foundation; 1985.

[90] The extent to which individuals can exercise democratic rights depends on the size and density of the population, as anyone who has lived in a large apartment block will confirm. Under certain conditions, some democratic rights thus become ungrantable. Fifty billion humans living on earth, even if they could be fed, would probably be stacked up in tanks from birth, with very little individual autonomy or rights.

[91] It has been repeatedly proposed that all life forms and natural communities have interests (Singer P. Animal liberation. New York, NY, USA: New York Review Books; 1975). The fact that we may not know what exactly their interests are should not prevent us from imparting on them a certain moral standing (Sagoff $M$. Has nature a good of its own? In: Costanza R, Norton BG, Haskell BD, editors. Ecosystem health. Washington, DC, USA: Island Press; 1992. pp. 57-71.) and respect (Taylor P. Respect for nature: A theory of environmental ethics. Princeton, NJ, USA: Princeton University Press; 1986).

[92] Simonsen $\mathrm{SH}$, Biggs RO, Schlüter $\mathrm{M}$, Schoon M, Bohensky E, Cundil G, Dakos V, Daw T, Lotschy K, Leitch A, Quinlan A, Peterson G, Moberg F. Applying resilience thinking: seven principles for building resilience in social-ecological systems. Stockholm Resilience Centre; 2014. Available from: www. stockholmresilience.su.se.

[93] Costanza R. Toward an operational definition of ecosystem health. In: Costanza, R, Norton BG, Haskell BD, editors. Ecosystem health: New goals for environmental management. Washington, DC, USA: Island Press; 1992. pp. 239-257.

[94] Callicott JB. Animal liberation: A triangular affair. Environmental Ethics. 1980;2(Winter):311-338.

[95] Hardin G. Carrying capacity as an ethical 
concept. In: May L, Wong K, Delston J, editors. Applied ethics: a multicultural process. 5th edition. Toronto, Canada: Prentice Hall; 2011. pp. 186-194.

[96] Crisp N. Turning the world upside down: The search for global health in the 21st century. London,
UK: Royal Society of Medicine; 2010.

[97] Coole D. Too many bodies? The return and disavowal of the population question. Environmental Politics. 2013;22(2):195-215. 